\title{
AN APPROPRIATE HUMAN BODY WASTES DISPOSAL SYSTEM FOR WATERFRONT DWELLERS IN PORT HARCOURT METROPOLIS
}

\author{
Ayotamuno M.J' ${ }^{1}$ Olatunji O.M², Annie $\mathbf{I}^{3}$ \\ ${ }^{I}$ Department of Agricultural and Environmental Engineering, Rivers State University of Science and Technology, \\ PMB 5080, Port Harcourt, Nigeria \\ ${ }^{2}$ Department of Agricultural and Environmental Engineering, Rivers State University of Science and Technology, \\ PMB 5080, Port Harcourt, Nigeria \\ ${ }^{3}$ Department of Agricultural and Environmental Engineering, Rivers State University of Science and Technology, \\ PMB 5080, Port Harcourt, Nigeria
}

\begin{abstract}
In this study, analysis of an appropriate toilet system for the slums of Port Harcourt metropolis was carried out in order to improve the existing toilet system for the slums within the metropolis. Disposal of human feaces is one of the pressing public health problems in most of the urban areas. A critical look at the existing toilet systems of the slums was observed and analyzed. Considerations were made with respect to the slums, environmental factors, provision of sanitation system, physical, social and cultural factors. Four different locations were sampled this include Elabuchi, Marine Base, Abonnema Wharf and Nember Waterside. At Elabuchi 165 households disposes faeces directly into the River while 25 house holds have bucket latrine. At Marine base, 65 households disposes faces directly into the river, while 25 households have bucket latrine. Abonnema Wharf has 80 households disposing feaces directly into the river while 10 households have bucket latrine and for Nembe waterfront has 75 households disposing faeces directly into the river while 15 households have bucket latrine. A comparison of composted and uncomposted feaces was observed. The result showed that composting reduced ascarid egg count to zero while the un-composted does not which is why the composting privy is regarded as one of the prospective alternatives and favourable as a tool to accomplish sustainable sanitation system, because it can utilize human excrements as compost. A safe recycling of this feaces will benefit agricultural production and to reclaim swamps is more desirable.
\end{abstract}

Keywords: Analysis, Composting privy, double chamber and Toilet system, Water front

\section{INTRODUCTION}

Inappropriate toilet system and increasing urbanization represent serious contemporary concerns for many municipalities, industries and the entire society. Several factors have contributed to these problems, continued population growth in urban areas, the financial status of the citizens and their level of education. Mapping and assessment of all slums is important for locating the toilet of the slums. The urban slum is one major area where so much improperly managed sewage is generated. The sewage generated here is enormous and so is the effort needed for its management. Effective toilet system can prevent negative environmental imparts associated with sewage [1]. Base on this fact, it is obvious that responsible environmental management of the toilet system of the slums is necessary for improve health of the settles. A realistic frame work has emerged for considered a better and an appropriate means of improving the toilet system which may not use water and repairs of maintenance operation is without odor, [2]. In building an appropriate toilet capacity to build and maintain the appropriate toilet system is the means of sewage disposal which is most convenient and environmentally analysis of the existing toilet system in the slum dwellers. The analysis of the existing toilet system in the slums of Port Harcourt and the toilet system is undertaken. Due to increase in both population and urbanization expansion and the demand for quality water in the area, there is a need for government to come upon with programmes to solve this swage disposal problem which has not been embarked upon since the creation of this state.

Therefore to avert this problem and make an appropriate means of sewage disposal available to the slums, there is a need to treat the issue of polluted environment due to the poor or inappropriate means of toilet system in these slum areas. This study investigates the possibilities of providing an appropriate toilet system in the slum of Port Harcourt. It is aimed at improving the toilet system for the slums of Port Harcourt from the analysis of existing systems. Therefore objectives are:

i. Study the available system in use

ii. Analyze the various types of systems applicable to similar situation

iii. Recommend an appropriate toilet system for waste recycling and improvement of sanitation of the environment.

With the aim of reducing the morbidity rate and the environmental hazards which occur due to infectious bodies within the slums. Among the criteria developed, condition is the most important consideration which inevitably limits the options for the slum areas. This factor systems can be built 
above the ground or those without soil requirement are favourable for the community. These include the composting privies bucket latrines, vaults and cartages, shallow sewer system and the small bore sewers [9]

Environmental factors are the key determinants for differentiating the slum communities from other types of communities. These factors include; condition of the slum area, option for disposing human faeces, [5].

Toilet systems even when they are properly designed may not be appropriate when social and cultural factors affecting the toilet and hygiene practices of the community members are not considered, [6]. He also stated that technologies involving reuse of excreta are unfeasible in communities where sight or handling of faeces is culturally and socially unacceptable. In the same way, dry technologies such as the use of papers are inappropriate for slum communities which community is defecation vary; but gradually, it is regarded as a private personnel act.

In slum communities that require a high level of privacy, the design of these requirements; the number of persons served by the toilet, how the used and maintain the toilet is important, [1].

The compositing privy on the other hand, involves the handling of faecal wastes only when the excreta has been transform into non-offensive, less harmful humus. Culturally, the most important distinction in the choice of an appropriate toilet system is dependent on where the community regards human faeces as valuable resources or view it as an unpleasant and dangerous waste product, $[1,8]$. Compositing toilets are classified as dry, on-site system which have no soil requirement and can be built above the ground, [2]. They can be used under the most difficult soil and ground water condition, [1].

The term compositing ahs been defined as a biological process for converting organic solid waste into a human like product whose chief use is as soil conditioner, [3, 4]

The double vault composting privy has two adjacent vaults, one which is used until it is about three quarter full, when it is filled with earth and sealed, the other vault is used. Ash and organic matter are added to the vault before it is sealed to absorb odor and moisture. The tanks are paved and are constructed above the ground so as not to be submerged by rain water, $[4,11]$. The compositing privy which can be built above the ground is technically feasible. Careful design and construction is required to avoid water filtration into the composting chamber. The narrow walk ways pose limitations to the use of technologies requiring the use of trucks or carts for transporting the faecal waste, $[2,7]$.

\section{MATERIALS AND METHODS}

Port Harcourt basically comprises of two major Local Government Areas. There are Port Harcourt City Local Government Area and Obio/Akpor Local Government Area. Stretching from Borikiri on the southern most parts to
Rumuodumaya and Ozuoba, and Elelenwo in the northern most part of Rebisi communities respectively. The city has the second largest seaport in Nigeria. It is located on the Bonny River about $64 \mathrm{~km}$ (40miles) from the sea. It is located at longitude $07001 \mathrm{E}$ and latitude $4051 \mathrm{~N}$. The city is slightly elevated, dips gently south west - ward and angle of 10 to 50 but no significant structural control on the evolution of the drainage network and surface. The city has about four different slums located at the southern most parts. These slums include; the Iluabuchi water front, the marine base water front, the Abonema Warf waterfront and the Nembe water front. The most populated slum is the Iluabuchi water front. This district consists of different streets and each street has 55 to 60 resident structures at the slum. Out of the four different water fronts, three were randomly choosen and from these three, 50 households were randomly selected for study. According to local statistics at June 2009, population of these different slum studied were between 450 to 500 with each household having about six or more persons. It has an area of $0.03 \mathrm{~km} 2$, so houses are standing tickly having widths of $1 \mathrm{~m}$ to $2 \mathrm{~m}$, such that cars or trucks cannot enter. Field investigation of these selected slum sites has been carried out to reveal actual conditions relating to their present means of sewage disposal, their utilization characteristic of the existing toilet system, their sanitation habit and cultural behaviours.

This data was obtained by casual observations and questionnaires distributed to the selected households. The dimensions of the present systems in use were obtained using tapes and the volume of human faecal waste produced per day was also estimated using the amount produced per normal adult per day by weighing the average collected quantity for 20 individuals and multiplying by the total number of people in the household. The distance between the households and the toilet were measured using tapes. This shows that distances from the houses to toilet were very close and infectious bodies within that environment. From observations of the direct stooling into the rivers, the processes that the human waste produced undergo were observed during these periods of visits; such as the floating processes and the drying processes.

From the information gotten from the people who use the bucket latrine, the faeces were usually evacuated after every 2 to 3 days intervals at night, depending on the number of persons using that particular bucket. From the information gotten from the people who used the bucket latrine, the bucket faces were usually evacuated after every 2 to 3 days intervals at night depending on the number of persons using the particular bucket.

The principle used in analyzing this data is, the average quantity of faecal waste produced by an individual (W), which was obtained using this equation;

$$
W=\frac{\text { summation of } w i}{20}
$$

$W i=1-20$ 
$W i=$ average collected quality of faeces for 20 individuals.

$$
W g c=\frac{W T-W c}{p d} \frac{\frac{k g}{c a p}}{d a y}
$$

Where:

$\begin{array}{lll}\mathrm{Wgc} & = & \text { Faecal waste generated per capital per day } \\ \mathrm{WT} & = & \text { Total weight of faecal waste } \\ \mathrm{W}_{\mathrm{C}}= & \text { Weight of Container } \\ \mathrm{P} & = & \text { Population served } \\ \mathrm{d} & = & \text { Number of days used before evacuation }\end{array}$

The bulk density of the waste component was computed using:

$l_{d}=$ density of faecal waste

$V w=$ volume of faecal waste

$W C=$ weight of container

\section{RESULTS AND DISCUSSION}

Human excrements are discharged into natural water body without treatment. Floating faeces in channels are visible at high tides all the time. The direct defecation system into the rivers is housed under thatched or walkways. In areas where the bucket latrine is used, the principle involves defecating into a container which is removed for disposal periodically into swamps or on land, it can easily be filled and required periodic evacuation, for high density areas. Major restricting factors in the usage of the bucket latrine in these slum communities are the rejection of waste handling and the use of water for anal cleaning. There are other problems such as odor from the open bucket, breeding of all types of insects and rodents, spillage of the waste from leaks of bucket and unsanitary conditions at the collection and transfer points in the actual use of this system.

About $75 \%$ of the inhabitants stool directly into the river, while $15 \%$ use the bucket latrine

Table 1 The distribution of the direct disposal system and the bucket system in the slum communities

\begin{tabular}{|l|l|l|}
\hline $\begin{array}{l}\text { Slum communities } \\
\text { (Water Fronts) }\end{array}$ & $\begin{array}{l}\text { Direct disposal } \\
\text { faeces into the } \\
\text { river }\end{array}$ & Bucket Latrine \\
\hline Iluabuchi & 165 & 25 \\
\hline Marine Base & 65 & 25 \\
\hline Nembe Water Front & 75 & 15 \\
\hline Abonnema Warf & 80 & 10 \\
\hline
\end{tabular}

A critical aspect in the planning stage of providing communal toilets in slum communities is determining the most strategic location of the facility, considering accessibility and proximity to the users. In most areas, a large percentage of the households in these communities has encroached on the water so that their proximity to the ideal sites for the facility is decreased.
Thus determining the most strategic location for the facility involves the analyses of trade off, between user accessibility and convenience and the cost of the facility. Compounding the difficulties with the provision of communal toilets are usage and maintenance problems. Public toilets seem to belong to no one and thus there as very little commitment by the individual users to keep it clean and operating properly. The above two systems used are inappropriate for the following reasons;

For the bucket latrine the observed in the Port Harcourt metropolis disadvantages are as follows:

i. It involves the evacuation of the bucket within a short period

ii. It is not suitable for high density areas

iii. Produced odor from the open bucket

iv. It provides room for breeding of insects and rodents

v. There is spillage of the faecel watery waste from the leakages of the bucket.

vi. Provides an unsanitary condition at the collection and transfer points.

vii. Problem of transportation in areas where access is very difficult.

For the direct stooling into the river, the observed disadvantages in the Port Harcourt Metropolis are:

i. Increasing BOD that reduces the number of flaura and fauna in the system, particularly the number of fishes available for fishermen in the area, knowing that their major business is fishing. The few fishes that survive the situation feed on the untreated excrements thereby providing avenue for the transfer of disease among the inhabitants.

ii. It pollutes the river knowing that most time the water from the river is been used for domestics (washing and cooking) and also for drinking thereby causing sporadic infectious water borne diseases to man.

iii. The nearness of the houses to the toilets also causes some environmental hazards to human health.

The idea of defecating directly into the river causes water pollution. This implies that the quality of the water has been degraded. Degradation refers to a decline in water quality by chemical, physical or biological means which is usually determined by the intended use of the water. Raw faeces contains high amount of dissolved organic material and therefore create a high BOD load when dumped into water. Various types of toxic substances can become a threat to human health when unrestricted discharge is allowed to occur. Also, bacteria and viruses may be transmitted to humans when these faeces enter into surface water. Viruses such as the hepatitis virus present an additional danger since they are unusually resistant to water treatment procedures.

Consequently, it is important to provide an appropriate toilet system which will reduce or minimize the negative effects of the afar mentioned system in use. 
Table 2: Physical and chemical quality of compost

\begin{tabular}{|l|l|l|}
\hline Test & Raw Feaces & Compost \\
\hline Wet weight (kg) & $1.80 \pm 0.10$ & $1.75 \pm 0.03$ \\
\hline Dry weight (kg) & $0.77 \pm 0.01$ & $0.67 \pm 0.30$ \\
\hline Moisture content (\%)w.b & $61.20 \pm 0.76$ & $61.70 \pm 0.79$ \\
\hline Bulking density (kg/m $\left.{ }^{3}\right)$ & $0.12 \pm 0.01$ & $0.11 \pm 0.02$ \\
\hline Bulding density (kg/m $\left.{ }^{3}\right)$ & $0.21 \pm 0.01$ & $0.30 \pm 0.02$ \\
\hline Specific gravity & $1.84 \pm 0.01$ & $2.31 \pm 0.07$ \\
\hline Porosity (\%) & $93.5 \pm 0.30$ & $95.2 \pm 0.10$ \\
\hline Air space (\%) & $36.3 \pm 0.13$ & $36.5 \pm 0.42$ \\
\hline Total Solid (\%) T.S \pm & $39.7 \pm 0.18$ & $39.3 \pm 0.15$ \\
\hline Ash \% T.S & $15.9 \pm 0.22$ & $18.8 \pm 0.15$ \\
\hline Volatile solids (\%) T.S & $92.5 \pm 0.13$ & $89.6 \pm 2.09$ \\
\hline Phosphorus (\%) d .b & $1.46 \pm 0.01$ & $0.90 \pm 0.01$ \\
\hline Potassium (\%) d .b & $0.19 \pm 0.01$ & $0.16 \pm 0.02$ \\
\hline Nitrogen (\%) d .b & $0.06 \pm 0.02$ & $1.30 \pm 0.02$ \\
\hline Carbon (\%) d .b & $46.7 \pm 1.35$ & $45.1 \pm 0.17$ \\
\hline C/N & $44.1 \pm 0.32$ & $34.7 \pm 0.80$ \\
\hline $\mathrm{P}^{\mathrm{H}}$ & $7.6 \pm 0.31$ & $8.1 \pm 0.18$ \\
\hline
\end{tabular}

Table 3: Bacteriological quality of compost (Ascarid egg mortality \%)

\begin{tabular}{|l|l|l|l|l|}
\hline Test & \multicolumn{2}{|l|}{$\begin{array}{l}\text { Before Compositing } \\
\text { (egg count) }\end{array}$} & \multicolumn{2}{l|}{$\begin{array}{l}\text { After Composting } \\
\text { (egg count) }\end{array}$} \\
\hline & Alive & Dead & Alive & Dead \\
\hline $1^{\text {st }}$ & 76 & 24 & 0 & 100 \\
\hline $2^{\text {nd }}$ & 70 & 30 & 0 & 100 \\
\hline
\end{tabular}

The most appropriate system for the condition of the water front dwellers is the double chamber composting privy. It is necessary to consider the evaluating compositing toilet as one of alternative system to the direct disposal and bucket systems. The sanitation system with compositing toilet is fundamentally different from all others. The application of which discharges waste water is worth to consider as one of alternatives. The replacement of sawdust with new one in the system should be carried out several times in a year. withdrawn sawdust can be used as compost for gardening and for farms, it can also be used to recover swamp areas, amount of generated compost becomes considerable. A means to collect the compost and carry them out of the slum is to be made available. We should develop the culture of using human excrement as a compost or fertilizer in farmlands for promoting organic farming and also to fill up swamp areas.
Functional Elements for Faecal Waste Management System The activities associated with the management of faecal waste from the point of generation to final disposal have been grouped into six functional elements.

i. Faeces generation

ii. Faeces handling and separation, storage and processing

iii. Collection from sources

iv. Separation, processing and transformation of faecal wastes

v. Transfer and transport

vi. Final disposal

\subsection{Population}

A total population of 542,028 person was estimated for the 33 waterfronts. The population of a given waterfront was calculated using the following formula:

$$
\text { Population }=\mathrm{Q} \times \mathrm{R} \times \mathrm{H}
$$

Where,

$\begin{array}{lll}\mathrm{Q} & = & \text { average number of persons per room } \\ \mathrm{R} & = & \text { average number of rooms per house } \\ \mathrm{H} & = & \text { average number of houses per waterfront }\end{array}$

Therefore the population of the entire waterfront was calculated by:

$$
\text { Waterfront population }=\sum_{i}^{33} Q \times R \times H
$$

Table 1 shows the names of the waterfronts, the average number of the houses, the average number of rooms per house, the average number of persons per room, and the population per waterfront. There are about 10,192 houses in the entire waterfront. Marine Base is the largest waterfront in land area and population, followed by New Bundu. The size of each of the compounds or houses is less than half of a plot, so that there is much overcrowding in and around the dwellings.

\begin{tabular}{|c|c|c|c|c|}
\hline Name of Waterfront & $\begin{array}{l}\text { Average } \\
\text { Number } \\
\text { Houses }\end{array}$ & $\begin{array}{l}\text { Average } \\
\text { Number } \\
\text { Rooms }\end{array}$ & $\begin{array}{l}\text { Average } \\
\text { Number } \\
\text { Persons } \\
\text { Room }\end{array}$ & Population \\
\hline Baptist & 497 & 10 & 6 & 29,820 \\
\hline Ndoki & 328 & 8 & 6 & 15,744 \\
\hline Bishop Johnson & 507 & 8 & 6 & 24,336 \\
\hline Rex Lawson & 464 & 8 & 6 & 22,272 \\
\hline Orupolo & 235 & 8 & 6 & 11,280 \\
\hline Captain Amangala & 488 & 8 & 6 & 23,424 \\
\hline Ibadan & 467 & 10 & 6 & 28,020 \\
\hline Nembe & 339 & 8 & 6 & 16,272 \\
\hline
\end{tabular}

Table 4: Average number of houses and population distribution in each of the waterfronts studied. 


\begin{tabular}{|l|l|l|l|l|}
\hline Dockyard & 206 & 8 & 6 & 9,888 \\
\hline New Bundu & 774 & 10 & 6 & 46,440 \\
\hline Old Bundu & 556 & 10 & 6 & 33,360 \\
\hline Enugu & 578 & 8 & 6 & 27,744 \\
\hline Bonny & 230 & 8 & 6 & 11,040 \\
\hline Okrika & 269 & 8 & 6 & 12,912 \\
\hline Marine Base & 829 & 10 & 6 & 49,740 \\
\hline Okujagu & 286 & 8 & 6 & 13,728 \\
\hline Ogu & 308 & 10 & 6 & 18,480 \\
\hline Comprehensive & 195 & 10 & 6 & 11,700 \\
\hline Enotonia & 167 & 8 & 6 & 8,016 \\
\hline Naval & 184 & 8 & 6 & 8,832 \\
\hline NEPA & 227 & 8 & 6 & 13,295 \\
\hline UST & 185 & 10 & 6 & 11,100 \\
\hline Timber & 147 & 8 & 6 & 7,056 \\
\hline Nanka & 136 & 8 & 6 & 6,528 \\
\hline Ojike & 124 & 8 & 6 & 5,952 \\
\hline Elechi & 285 & 8 & 6 & 13,680 \\
\hline Ejimanze & 146 & 8 & 6 & 7,008 \\
\hline Abonnema & 299 & 12 & 6 & 21,528 \\
\hline Akokwa & 165 & 8 & 6 & 7,920 \\
\hline Afikpo & 148 & 8 & 6 & 7,104 \\
\hline Egede & 137 & 8 & 6 & 6,576 \\
\hline Ogbogoro & 109 & 8 & 6 & 5,232 \\
\hline Yam Zone & 125 & 8 & 6 & 6,000 \\
\hline
\end{tabular}

\section{CONCLUSIONS}

In coastal and water from communities, disposal of human feaces into the surface water of ground without treatment is prevalent. This habit is unhygienic since there are cases wherein the surface water is also the source of water for cleaning. In other communities, the surface water is stagnant thus increasing the pollution problems. Disposal of treatment without treatment is not justifiable especially in the transition areas where accumulated toilet feaces obstruct water waves. Human excreta with saw dust as bulking agent can be used for production of manure which will enhance crop production. The results gotten from the analysis of such manure shows that it is environmentally friendly.

\section{REFERENCES}

[1] Burubai, W., Akor, A. J. (2004). Design and Evaluation of a Double Chamber compositing privy, Journal of Agricultural and Environmental Engineering Technology: ISSN 1547 - 5355, vol.1, pp $136-139$.

[2] Gunnerson, C. G. (1982). Appropriates Sanitation alternative; a planning and design manual; Baltimore: John Hopkins University Press, Vol.1 pp.21-22.

[3] Rodale Kalbermatten, J.M. and Julius. S.D. (1980): Appropriate Technology for water supply and sanitation. A sanitation field manual.

[4] Lens, P. Zeeman, and Lettinga, G. (2001): Decentralized sanitation and Reuse; concept, system and implementation. W. A. publishing Vol.1 pp.32.

[5] McGarry, G. M., and Stainforth, J. (1988). Compost, Fertilizer and Biogas Production from Human and arm wastes in the peoples republic of China. Journal of Sanitation, vol.30 pp25.

[6] Mc Garry, G.M., Witold, R., and Chongrak, P. (1978). Lowcost technology options for sanitation: A state-of the Art. Review and Annotated Bibolography Ottowa: International Development Research Centre. Vol.1 pp.16-18.

[7] Ohmachi, T. and Roman, E. (2002). Composting and hygiene, Metromanila in search of a sustainable future, University of the Philippines press, vol.3. pp 102-104.

[8] Saito, M. and Uchisawa, J. (1998). Voyage of Feaces, Shogakukan, vol.31.pp.66-71.

[9] Sintawardani, N., Irie, M., Triastuti, J., Ishikawa, T. and Affendi, M. (2005). feasibility of introducing the bio-toilet to decrease the water pollution in an open canal; a case study in kiara condong slum area in Bandung city. Future of urban waste water system decertratization and reuse. International Water Association conference. Vol.2 pp.101-109.

[10] Unisuga, S. and Watanable, T. (2004). Present condition of Environment control in Indonesia (2), Life and environment, Indonesia press, vol.49.pp.5762.

[11] Uno Winblad and Wen Kilama, (1980); Sanitation without water Stockholm; Swedish international development authority, Vol.2 pp.23. 